\title{
PERFORMANCE ASSESSMENT OF SCHOOL HEADS IN IMPROVING PROFESSIONALISM IN NEGRI BINAAN BASIC SCHOOLS IN KECAMATAN BUKIT SUNDI, SOLOK DISTRICT, INDONESIA
}

\author{
Rahmi Septia Sari ${ }^{1 i}$, \\ Silvia Anggreni BP², \\ Rusdinal ${ }^{3}$, \\ Nurhizrah Gistituati ${ }^{4}$ \\ ${ }^{1}$ Apikes Iris Padang, \\ Indonesia \\ 2STKIP Yayasan Abdi Pendidikan Payakumbuh, \\ Indonesia \\ 3,4Universitas Negeri Padang, \\ Indonesia
}

\begin{abstract}
:
The Principal's Performance Assessment is carried out at the target schools which are the responsibility of the school supervisor. After the Principal's Performance Assessment was carried out at the target schools for the 2019/2020 Academic Year, the results were different from one school to another, even though they were under the same supervision of a supervisor. This is because the management and abilities of each school principal are different. With this Principal Performance Assessment, each school should be able to find a solution or try to display the school's color as best as possible. Based on the results of the assessment every year there must be improvements or improvements in the results achieved. Principal performance appraisal activities are carried out by supervisors at each target school for which they are responsible. When carrying out the assessment, the school supervisor conducts interviews, checks documents in accordance with the statement of each item in the instrument. The school supervisor gives an assessment of each item in the instrument according to the facts found at that time and no longer provides an opportunity for the principal to provide and complete something desired in the statement. Such actions are taken by supervisors, because the physical evidence required by the instrument statement must be carried out by the principal before the assessment takes place, especially since this activity is routine work every year.
\end{abstract}

Keywords: performance, professionalism, headmaster, elementary schools

${ }^{\mathrm{i}}$ Correspondence: email rahmiseptiasari88@gmail.com 


\section{Introduction}

To realize the professionalism of school principals, supervision is necessary in assessing the performance of school principals. Assessment of the performance of school principals is one of the coaching strategies to maintain professionalism in carrying out duties, careers, increasing competence, and ensuring the quality of education. Educators and education staff standards are one of the strategic elements in improving the quality of education. The main focus of assessing the performance of school principals is how to improve the professional abilities of principals in a planned manner through a continuous quality improvement process. Therefore, quality developments need to be mapped periodically so that the profile of the principal based on measurement data can be realized. In accordance with Permendiknas Number 13 of 2007 concerning School Principal Standards and Permendiknas Number 28 of 2010 concerning the Assignment of Teachers as School Principals.

The position of school principal is an additional task given to teachers to lead and manage schools in carrying out the learning process. The success of education in a school is very dependent on the leadership of a school principal. The principal must be able to achieve the goals set and be able to see changes in a better life of globalization. Because there are rules and duties that must be carried out by the principal, sometimes not all of them carry out well.

Operationally, the principal duties of the school include the activities of exploring and utilizing all school resources in an integrated manner in an effective and efficient manner. Even though this is a discourse, the rules and duties for the principal can be an idea and an idea in improving the quality of education. Especially now that the duties and responsibilities of a school principal are getting heavier.

So far, the principal has a teaching load of 6 hours of lessons per week. This is because the position of principal is an additional task given to a teacher. In reality on the ground, many principals do not carry out the learning process in front of the class because they are overwhelmed in carrying out managerial tasks. Basically, a school principal is a manager to manage all resources in the school. The duties of the principal are administrative, staffing, financial, and other matters which take up quite a lot of time and energy so that there is no need to add more to teaching.

Under the new regulation, principal periodization will be eliminated, no longer using a four-year cycle. In addition, there is no longer the obligation to replace the principal after one or two terms. If the performance is not satisfactory, the principal can be dismissed and replaced. Thus a school principal has the opportunity to be able to serve until retirement if he is able to show good performance.

\section{Literature Review}

The literature review discusses the importance of the principal's ability to manage the school he leads, along with the explanation. 
In accordance with the opinion of Sumiwadjo (2003: 28-29) explains that leadership is one of the management functions, which is very important to achieve organizational goals. Leadership in terms of personal characteristics, influence on others, patterns of interaction of cooperative relations between positions from one administrative position and profession from another regarding legitimacy.

The appearance (performance) of the principal's leadership is the achievement given by the leadership of a principal, both quantitatively and qualitatively, which are exchanged in helping to achieve school goals. The principal as a person who is given the task to lead the school, is responsible for achieving the school's roles and responsibilities. The principal acts as a catalyst in the sense of being able to generate and move the enthusiasm of teachers, staff, and students, in achieving the goals that have been set. Broken spirit, loss of trust must be resurrected by the principal. The principal must be able to bring about changes in the behavior, attitudes, and intellectuals of students in accordance with educational goals.

\section{Material and Methods}

This study uses a descriptive method, which describes a number of variables under study. The design used in this research is a descriptive study in the form of a survey. Methods of data collection are carried out through observation, questionnaires, in-depth interviews and literature study. While the research instrument (tool) is to record observations, interview guidelines, cite literature (books, texts, documentation, archives, journals, articles in printed mass media).

Primary data is obtained from the results of respondents' answers through a questionnaire in the form of a set of questions that logically relate to the research problem. The research questionnaire consisted of closed questions (close form questionnaire). The population in this study was the principal in the kinari village, Bukit Sundi sub-district, Solok regency. The sampling technique uses random sampling technique. Data analysis aims to make the data simplification process easier to read and interpret. The data obtained from respondents is data from questionnaires with closed questions to obtain data on an ordinal scale. The answers to the questionnaire from this study will produce data with an ordinal scale. Data were analyzed using descriptive analysis which describes a number of variables studied.

When carrying out the assessment, the school supervisor conducts interviews, checks documents in accordance with the statement of each item in the instrument. The school supervisor gives an assessment of each item in the instrument according to the facts found at that time and no longer provides an opportunity for the principal to provide and complete something desired in the statement. Such actions are taken by supervisors, because the physical evidence required by the instrument statement must be carried out by the principal before the assessment takes place, especially since this activity is routine work every year. 


\section{Results and Discussion}

The following is a description of the results of research on the performance of school principals in order to see the professionalism of principals in their duties. The discussion of the results of this study is based on an assessment questionnaire conducted by the School Superintendent. The following is a descriptive research data analysis:

Tabel 3.1: Recapitulation of School Performance Assessment Score

\begin{tabular}{|c|c|c|c|c|c|c|c|c|}
\hline $\begin{array}{l}\text { School } \\
\text { Name }\end{array}$ & $\begin{array}{c}\text { SDN } \\
01 \\
\text { MP } \\
\end{array}$ & $\begin{array}{c}\text { SDN } \\
02 \\
\text { MP } \\
\end{array}$ & $\begin{array}{c}\text { SDN } \\
10 \\
\text { MP } \\
\end{array}$ & $\begin{array}{c}\text { SDN } \\
14 \\
\text { MP }\end{array}$ & $\begin{array}{l}\text { SDN } \\
18 \mathrm{MP}\end{array}$ & $\begin{array}{c}\text { SDN } \\
20 \\
\text { MP }\end{array}$ & $\begin{array}{c}\text { SDN } \\
12 \\
\text { DLM } \\
\end{array}$ & \multirow{2}{*}{$\begin{array}{l}\tilde{0} \\
\frac{\pi}{\omega} \\
\frac{\pi}{\pi} \\
\frac{\pi}{\pi} \\
\frac{\pi}{\pi} \\
\approx\end{array}$} \\
\hline 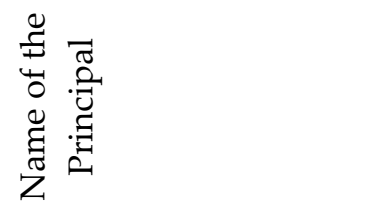 & 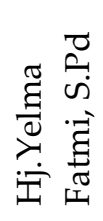 & 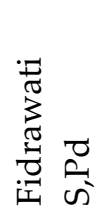 & 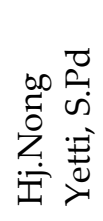 & 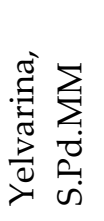 & 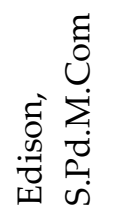 & 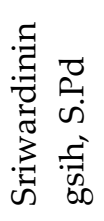 & 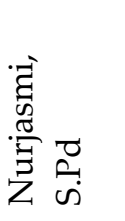 & \\
\hline \multicolumn{9}{|c|}{ Performance Appraisal of School Principals (PKKS) } \\
\hline Personality and Social & 2,86 & 3,14 & 2,86 & 3,14 & 3,14 & 3,00 & 3,14 & 3,04 \\
\hline Learner Leadership & 3,50 & 3,50 & 3,50 & 3,50 & 3,60 & 3,50 & 3,50 & 3,51 \\
\hline School Development & 3,71 & 3,71 & 3,71 & 3,71 & 3,71 & 3,71 & 3,71 & 3,71 \\
\hline Resource Management & 3,13 & 3,13 & 3,00 & 3,00 & 3,13 & 3,13 & 3,13 & 3,09 \\
\hline Entrepreneurship & 3,60 & 3,60 & 3,60 & 3,80 & 3,60 & 3,60 & 3,80 & 3,66 \\
\hline Learning Supervision & 3,00 & 3,00 & 3,00 & 3,00 & 3,33 & 3,00 & 3,00 & 3,05 \\
\hline Total Score & 19,80 & 20,08 & 19,67 & 20,16 & 20,52 & 19,94 & 20,28 & 20,06 \\
\hline $\begin{array}{l}\text { Average Principal } \\
\text { Performance Appraisal }\end{array}$ & 82,49 & 83,68 & 81,96 & 83,99 & 85,48 & 83,08 & 84,51 & 83,59 \\
\hline
\end{tabular}

Based on the description of the achievement score of the principal's performance assessment above, it can be seen that the final score of each aspect of the assessment is:

Tabel 3.2: Recapitulation of the end of the

Performance Assessment of Heads of Development Schools

\begin{tabular}{|c|c|c|c|c|c|c|c|c|}
\hline $\begin{array}{l}\text { School } \\
\text { Name }\end{array}$ & $\begin{array}{c}\text { SDN } \\
01 \\
\text { MP }\end{array}$ & $\begin{array}{c}\text { SDN } \\
02 \\
\text { MP }\end{array}$ & $\begin{array}{c}\text { SDN } \\
10 \\
\text { MP }\end{array}$ & $\begin{array}{c}\text { SDN } \\
14 \\
\text { MP }\end{array}$ & $\begin{array}{c}\text { SDN } \\
18 \\
\text { MP }\end{array}$ & $\begin{array}{c}\text { SDN } \\
20 \\
\text { MP }\end{array}$ & $\begin{array}{c}\text { SDN } \\
12 \\
\text { DLM }\end{array}$ & \multirow{2}{*}{ 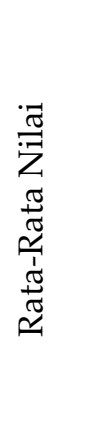 } \\
\hline 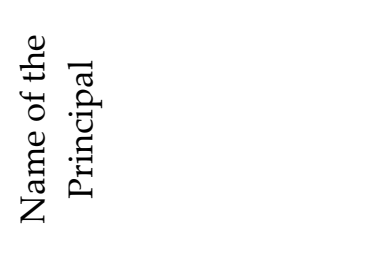 & 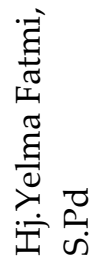 & 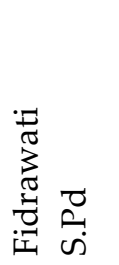 & 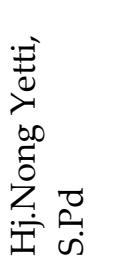 & 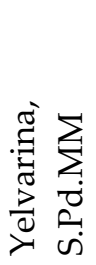 & 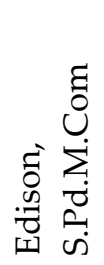 & 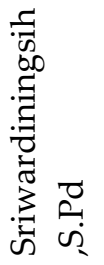 & 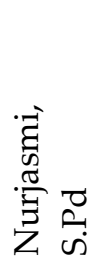 & \\
\hline \multicolumn{9}{|c|}{ Performance Appraisal of School Principals (PKKS) } \\
\hline Personality and Social & 71,50 & 78,50 & 71,50 & 78,50 & 78,50 & 75,00 & 78,50 & 76,00 \\
\hline Learner Leadership & 87,50 & 87,50 & 85,00 & 87,50 & 90,00 & 87,50 & 87,50 & 87,50 \\
\hline School Development & 92,75 & 92,75 & 92,75 & 92,75 & 92,75 & 92,75 & 92,75 & 92,75 \\
\hline Resource Management & 78,25 & 78,25 & 75,00 & 75,00 & 78,25 & 78,25 & 78,25 & 77,32 \\
\hline Entrepreneurship & 90,00 & 90,00 & 90,00 & 95,00 & 90,00 & 90,00 & 95,00 & 91,45 \\
\hline
\end{tabular}


Rahmi Septia Sari, Silvia Anggreni BP, Rusdinal, Nurhizrah Gistituati

PERFORMANCE ASSESSMENT OF SCHOOL HEADS IN IMPROVING PROFESSIONALISM

IN NEGRI BINAAN BASIC SCHOOLS IN KECAMATAN BUKIT SUNDI, SOLOK DISTRICT, INDONESIA

\begin{tabular}{|l|c|c|c|c|c|c|c|c|}
\hline \hline Learning Supervision & 75,00 & 75,00 & 75,00 & 75,00 & 83,25 & 75,00 & 75,00 & 76,18 \\
\hline Total Score & 495,00 & 502,00 & 489,25 & 503,75 & 512,75 & 498,50 & 507,00 & 501,20 \\
\hline $\begin{array}{l}\text { Average Principal } \\
\text { Performance Appraisal }\end{array}$ & 82,49 & 83,68 & 81,96 & 83,99 & 85,48 & 83,08 & 84,51 & 83,59 \\
\hline
\end{tabular}

\section{A. Data Analysis}

If from the data obtained in the recapitulation of the results of the assessment of the principal's performance that has been carried out, then in the following section an analysis of the results of the assessment will be carried out. The analysis was carried out on each school principal under the supervision of the supervisor. The results of the analysis of each principal performance assessment criterion can be seen in the following sections: 1) Personality and Social with an average score of 3.04 and an average final score of 76.00 in the "Enough" conversion. 2) Learning Leadership with an average acquisition score of 3.51 and an average final score of 87.50 are in the "Good" conversion. 3) School Development with an average acquisition score of 3.71 and an average final score of 92.75 is in the "Very Good" conversion. 4) Resource Management with an average acquisition score of 3.09 and an average final score of 77.32 in the "Enough" conversion. 5) Entrepreneurship with an average acquisition score of 3.66 and an average final score of 91.45 is in the "Very Good" conversion. 6) Learning Supervision with an average acquisition score of 3.05 and an average final score of 76.18 are in the "Enough" conversion. By referring to the data analysis above, the average score for the six principal performance assessment criteria is 19.88 and the final average score of 82.83 is in the "Good" conversion. The existence of the final value conversion is in accordance with the value range, namely: a) Less values ranging from $0-70, b$ ) Sufficient values ranging from 71 - 80, c) Good values ranging from 81 - 90, and d) Very good values ranging from 91 100. the upper limit of the value of each conversion has been set, but the supervisor who carries out the performance assessment of the principal stated, if the value has exceeded the upper limit, the conversion is at a stage above it.

\section{B. Follow-up}

In accordance with the description of the results of the analysis of the principal's performance appraisal, the mean score of achievement is 82.83 with the conversion of "Good." After analyzing the results of the principal's performance appraisal with the data obtained in the recapitulation, the following sections need to be followed up as follows: 1) Personality and Social Average value of 76.00 is in the "Enough" conversion, then each school principal should strive to meet which points are farthest from achieving good conversion. 2) Learning Leadership an average score of 87, 50 is in the "Good" conversion but it is necessary to strive to achieve a "Very Good" conversion by looking at which items should be improved. 3) School development mean score of 92.75 is in the "Very Good" conversion but also needs to try to fulfill which items are inadequate in order to get the "Very Good" conversion with praise. 4) Resource Management the average value of 76.82 is in the conversion of "Good" which is a little less, to get a good conversion that naturally requires hard work to meet which items are suggested. 5) Entrepreneurship with an 
average value of 90.00 is at the conversion of "Good", the upper limit to the conversion of "Very Good" by paying attention to which items must be improved in meeting the targets that must be achieved. 6) Learning Supervision the average value of 75.00 is in the conversion "Enough", far from the threshold to get the conversion "Very Good" because this activity is always neglected.

After analyzing the data and the follow-up of the results of the principal's performance appraisal, it can be concluded that the performance appraisal can see to what extent the principal's ability to carry out his main duties and functions as the principal in managing and improving the quality of education. The appearance and color of the school is largely determined by the competence of the principal in managing their respective schools. From the results achieved by each different school principal, it should be a whip or inspiration and the enthusiasm to race against each other to get a better assessment and compete healthily in a sense towards a positive direction.

Principal performance assessments are carried out periodically every year by the supervisors of the target schools. Meanwhile, the cumulative assessment every four years by the direct supervisor takes into account the performance appraisal by the assessment team consisting of: fostered supervisors, educators, educational staff, and school committees.

\section{Conclusion}

Assessment of the performance of school principals is a strategy for professional development in carrying out tasks, increasing competence, and performance. The main focus in assessing the performance of school principals is how to improve the professional abilities of principals that are planned through a process of continuous quality improvement. The position of school principal is an additional task given to teachers to lead schools through the management and learning process. The success of education in a school depends on the leadership of a school principal. The main duties of the principal in operation include activities to explore and utilize all school resources in an integrated manner within the framework of their effective and efficient attainment.

After seeing the results of the principal's performance appraisal carried out by the fostered supervisors, they should be motivated to improve and fulfill which assessment items have not been able to achieve good grades, even those that should have received very good grades. From the data analysis of the achievement of each aspect of the assessment, the Personality and Social aspects, Resource Management, and Learning Supervision are in the "Enough" conversion, so the principal must make every effort to improve it by fulfilling the points that need to be improved. It is different with the aspects of Learning and Entrepreneurship Leadership which have been in a "Good" conversion, but it takes effort to achieve a "Very Good" conversion. One aspect that has achieved "Very Good" conversion is School Development with an average score of 92.75.

Principal performance appraisal is the process of collecting, processing, analyzing, and interpreting data about the quality of the principal's work in carrying out his main 
duties as school principal. The principal task of the school principal is to carry out managerial functions in order to achieve the vision, mission and goals of the school he leads. The performance assessment of school principals that has been carried out by the fostered supervisors, shows that the average achievement is in the "Good" conversion, but there is also a need for improvements for the principal to improve the results to be achieved in the "Enough" conversion. The principal must pay attention to every aspect of which items need to be fixed or improved. The performance assessment of school principals carried out by the fostered supervisors is very helpful for school principals in managing their respective schools.

Such is the performance appraisal report for this principal that can be submitted by the supervisor of the target school. If seen and examined carefully, it may be far from perfect according to the actual rules. However, the supervisor has felt that this is far from the involvement and responsibility of a supervisor in his main duties and functions. As proof of the results of the activities that have been carried out by the fostered supervisors, it is herewith to attach some of the results of the tasks that have been carried out

\title{
Conflict of Interest Statement
}

The authors declare no conflicts of interest.

\begin{abstract}
About the Authors
Rahmi Septia Sari works at Apikes Iris Padang, Indonesia. His research interest is health school education. He published his research on health education, educational psychology.
\end{abstract}

Silvia Anggreni BP works at STKIP Yayasan Abdi Payakumbuh, Indonesia. Her research interest is civic education. The whole of her publishes research about civic education.

Rusdinal works at Universitas Negeri Padang, Indonesia; her research interest is education.

Nurhizrah Gistituati works at Universitas Negeri Padang, Indonesia; her research interest is education.

\section{References}

Armstrong, M. (2006). Performance Management: Key Strategies and Practical Guidelines. London and Philadelphia: Kogan Page. Third Edition.

Asmuni, Jamal, Ma'mur (2012). Tips Menjadi Kepala Sekolah Profesional. Yogyakarta: DIVA Press.

Bandura, A. (1997). Self-efficacy: The Exercise of Control. New York: W.H Freeman and Company.

Brenninkmeyer, L. D. \& Spillane (2008). Problem-Solving Process of Expert and Typical School Principals: A Quantitative Look. School Leadership and Management, Vol. 28, No. 5, November 2008. Page 435-468. 
Barbuto, John E. and Wheeler, Daniel W. (2006). Scale Development and Construct Clarification of Servant Leadership. Faculty Publications: Agricultural Leadership, Education \& Communication Department, page 51.

John E. Barbuto, J., Trout, S., \& Brown, L. (2021). Identifying Sources of Motivation of Adult Rural Workers. Retrieved 1 July 2021, from http://digitalcommons.unl.edu/aglecfacpub/5

Bernardin, H. J. \& Russell. J. E. A. (1993). Human Resource Management. Singapore: McGraw Hill Inc.

Carpenter, Mason., Tayla Bauer, Berrin Erdogan. (2010). Management Principles. Publisher: Flat World Knowledge, Inc.

Cerit, Yusuf (2009). The Effects of Servant Leadership Behaviors of School Principals on Teachers' Job Satisfaction. Journal Educational Management Administration $\mathcal{E}$ Leadership ISSN 1741-1432 DOI: 10.1177/1741143209339650, page 600-623.

Clark, Damon Paco Martorell, and Jonah Rockoff (2009). School Principals and School Performance, National Center for Analysis of Longitudinal Data in Education Research (CALDER), The Urban Institute.

Danim, S. (2004). Motivasi Kepemimpinan dan Efektivitas Kelompok. Jakarta: Rineka Cipta.

De Beer, M., Schurink, W. \& Barnard, A. (2008). A conceptual framework of integrity, South African Journal of Industrial Psychology,vol. 34, no. 2, pp. 40-49.

Duke, D. L. (1987). School Leadership and Instructional Improvement. New York: Random House.

Greenleaf, R. K. (1970). The Servant as Leader. Westfield IN: The Greenleaf Center for Servant Leadership.

Harris, B. M. \& Monk B. J. (1992). Personnel Administration in Education; Leadership for Instruction Improvement. Boston: Allyn and Bacon.

Haynes, Marion E. (1984). Managing Performance: A Comprehensive Guide to Effective Supervision. Belmont: Life-time Learning Publications. 
Author(s) will retain the copyright of their published articles agreeing that a Creative Commons Attribution 4.0 International License (CC BY 4.0) terms will be applied to their work. Under the terms of this license, no permission is required from the author(s) or publisher for members of the community to copy, distribute, transmit or adapt the article content, providing a proper, prominent and unambiguous attribution to the authors in a manner that makes clear that the materials are being reused under permission of a Creative Commons License. Views, opinions and conclusions expressed in this research article are views, opinions and conclusions of the author(s). Open Access Publishing Group and European Journal of Education Studies shall not be responsible or answerable for any loss, damage or liability caused in relation to/arising out of conflicts of interest, copyright violations and inappropriate or inaccurate use of any kind content related or integrated into the research work. All the published works are meeting the Open Access Publishing requirements and can be freely accessed, shared, modified, distributed and used in educational, commercial and non-commercial purposes under a Creative Commons Attribution 4.0 International License (CC BY 4.0). 